\title{
Determination of Optimal Irrigation Scheduling for Coffee (Coffee Arabica L.) at Gera, South West of Ethiopia
}

\author{
Etafa Tilahun $^{1^{*}, \text { Minda Tadesse }^{1}, \text { Addisu Asefa }^{1} \text { and Robel Admasu }}{ }^{2}$, Tesfaye Shimbir (Dr. $)^{3}$ \\ ${ }^{1}$ Jimma Agricultural Research Center P. Box 192, Jimma, Ethiopia \\ ${ }^{2}$ Debrezeit Agricultural Research Center \\ ${ }^{3}$ Ethiopian Institute of Agricultural Research, Addis Ababa, Ethiopia
}

*Corresponding Authors: Etafa Tilahun, Jimma Agricultural Research Center P. Box 192, Jimma, Ethiopia

\begin{abstract}
Afield experiment was carried out from 2011 to 2018 cropping seasons at experimental site of Gera agricultural research sub-center to investigate the effect of soil moisture depletion and to identify optimal soil moisture depletion level on growth, yield and water productivity of coffee Arabica (coffee Arabica L.) of variety 74165. The treatments consists of five allowable soil moisture depletion level (ASMDL), i.e, 60\% ASMDL, 80\% ASMDL, 120\% ASMDL, 140\% ASMDL and control irrigation of 100\% ASMDL. These five treatments were laid out in complete randomized block design with three replications. The irrigation water was applied based on allowable soil moisture depletion of $(p=40 \%)$ considered for coffee Arabica. The over year analysis of variance showed that soil moisture depletion level significantly $(P<0.05)$ affected coffee yield and water productivity. The average highest coffee yield of $2330 \mathrm{Kg} / \mathrm{ha}$ was obtained from the $120 \%$ ASMDL by applying $10145 \mathrm{m3} / \mathrm{ha}$ of water, while the FAO recommended treatment of $100 \%$ ASMDL produced the lowest yield of $1780 \mathrm{Kg} / \mathrm{ha}$. The $60 \%, 80 \%, 100 \%$ and $140 \%$ treatments were not statistically significant from each another. Therefore, $120 \%$ ASMDL treatment gave above mean value of yield and water productivity and hence can be used as the allowable soil moisture depletion for coffee Arabica (coffee Arabica L.) in a coffee growing area of Gera.
\end{abstract}

Keywords: ASMDL, Irrigation regime, coffee

\section{INTRODUCTION}

Water is the primary input for plant growth and food production. There is a competition among water users as many different uses of water resources are interdependent. Accurately estimating the volume of water required at different growth stages for crops is very essential for efficient use of available finite water resources. Furthermore, the knowledge of water requirement of crops allows to get maximum yields through controlling over or under irrigation problems such as water logging, salinization of soil and water stress to plant which can reduce yields of crops (Michael, 1999; Savva and Freken, 2002).

Coffee Arabica (coffee Arabica L.) is believed to be originated from Ethiopia and Jimma Zone is one of coffee growing zones in Oromia Regional State, however, its production system is traditional till now, where its productivity is severely affected by water shortage especially during critical stage of flowering and fruit set (Tadesse, 2019). Due to water shortage, the crop undergoes severe water-stress which affects yields. Coffee irrigation is a promising technique to increase yield and expansion of coffee plantations in areas considered unsuitable due to the occurrence of water shortage (Silva et al., 2008).

Irrigation scheduling is a viable technique to systematically determine the time and quantity of irrigation in individual fields where there is water shortage which depends on the available soil moisture depletion of the soil for the crop. By scheduling irrigation, producers can maintain the soil moisture above permanent wilting point levels and conserve water by avoiding unnecessary irrigation events. Allen et al., (1998) has expressed the moisture depletion level for coffee is 0.4. However, recommendations are needed at the operational environment since the crop water requirement is dependent on the type of the crop (variety) and climatic condition. 
Therefore, the determination of optimal irrigation schedule for coffee Arabica at Gera, South Western Ethiopia was formulated with the primary objective to recommend the allowable soil moisture depletion level for coffee Arabica in the agro ecology of Gera.

\section{Material AND MethodS}

\subsection{Description of the Study Area}

The study area is located at $7^{0} 7^{\prime} \mathrm{N}$ latitude and $36^{\circ} 4^{\prime} \mathrm{E}$ longitudes at an altitude of $1940 \mathrm{~m}$ a.m.s.l in Oromia region, Jimma zone, and $23 \mathrm{~km}$ West of Agaro town. The climate is cool and humid. The area receives an annual rainfall of $1906.3 \mathrm{~mm}$ per annum distributed unevenly throughout the year. It has the highest and lowest temperature of $24.4{ }^{\circ} \mathrm{c}$ and $10.4{ }^{\circ} \mathrm{c}$, respectively. The soil texture is classified as Sandy clay loam with $103 \mathrm{~mm} / \mathrm{m}$ of TAW. The study area represents one of the coffee growing areas in the country.

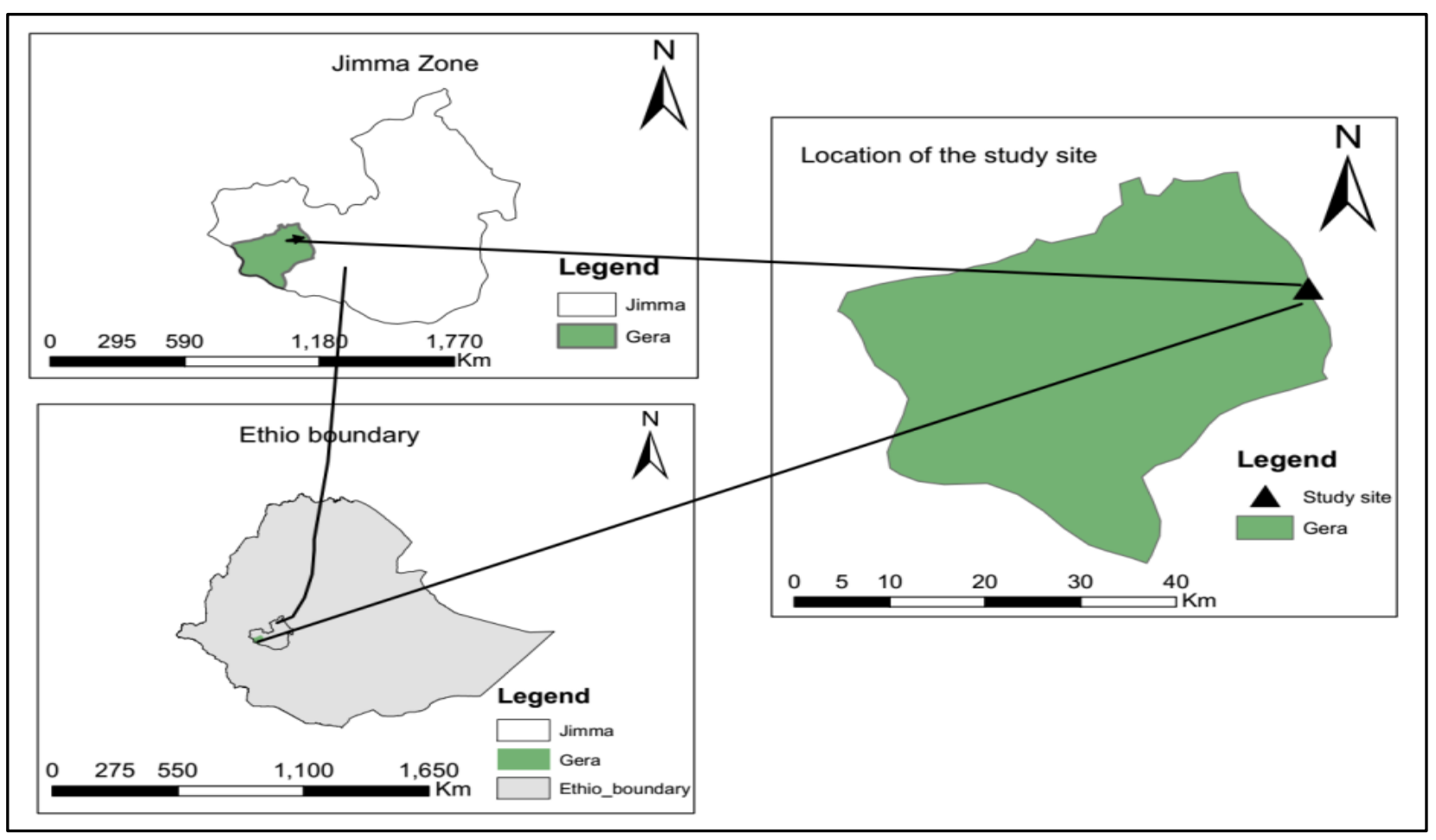

Figure1. Geographical location of the study area

\subsection{Experimental Treatment and Design}

The experiment was conducted at Gera agricultural research sub-center from 2011/2012 up to 2017/2018 on compact canopy coffee variety 74165. Randomized Complete Block Design (RCBD) with three replications was used following the procedure of Gomez and Gomez (Gomez, 1984). Five treatments of soil moisture depletion levels were assigned and randomized in the plots. The treatments are 60, 80,120,140\% and ASMDL (FAO recommended allowable soil moisture depletion level) and FAO recommended ASMDL assigned as a check. The optimal irrigation schedule (ETc) was computed with Cropwat model.

Each individual plot has an area of $10 \mathrm{~m} \times 12 \mathrm{~m}=120 \mathrm{~m}^{2}$. The recommended spacing of $2 \mathrm{~m}$ by $2 \mathrm{~m}$ between plants for coffee was employed. Each experimental treatment was fertilized with recommended fertilizer application rate of $172 \mathrm{~kg} / \mathrm{ha}$ and $63 \mathrm{~kg} / \mathrm{ha}$ of DAP and Urea, respectively. All agronomic and crop management practices were done to all treatments in accordance to the recommendation made for the area. Irrigation water was applied as per the treatment to refill the crop root zone depth close to field capacity.

\subsection{Data Collection}

Coffee yield and growth parameter were recorded, and the treatments were compared based on yield and growth parameter. Coffee yield was harvested from each plot and the experimental trees in the 
Determination of Optimal Irrigation Scheduling for Coffee (Coffee Arabica L.) at Gera, South West of Ethiopia

plot excluding border trees were used for analysis. Five representative coffee trees were randomly selected from each plot for growth parameter measurement. Plant height was measured at $5 \mathrm{~cm}$ from base to apex leaf using rod meter. The girth was measured at $5 \mathrm{~cm}$ from the base using caliper. The water productivity was calculated by the ratio of harvested yield per total water used.

$$
\mathrm{Wp}=\frac{\text { Harvested yield }}{\text { Total water used }}---------(1) \quad ; \text { Where, } \mathrm{Wp}=\text { water productivity }(\mathrm{kg} / \mathrm{m} 3)
$$

\subsection{Data Analysis}

Data collected were statistically analyzed using statistical analysis system (SAS) software version 9.0 using the general linear programming procedure (GLM). Mean separation was made using least significant difference (LSD) at 5\% probability level to compare the differences among the treatments mean. Long term meteorological data (Table 1) from Gera agricultural research sub-center was used to calculate the reference evapotranspiration and to compare the monthly rainfall and effective rainfall with evapotranspiration (Figure 2).

Table1. Long term meteorological data collected from Gera agricultural research sub-center

\begin{tabular}{|l|l|l|l|l|l|l|l|}
\hline Month & $\begin{array}{l}\text { Maximum } \\
\text { temperature } \\
\left({ }^{\circ} \mathrm{C}\right)\end{array}$ & $\begin{array}{l}\text { Minimum } \\
\text { temperature } \\
\left({ }^{\circ} \mathrm{C}\right)\end{array}$ & $\begin{array}{l}\text { Relative } \\
\text { humidity } \\
(\%)\end{array}$ & $\begin{array}{l}\text { Wind } \\
\text { speed } \\
(\mathrm{m} / \mathrm{s})\end{array}$ & $\begin{array}{l}\text { Sunshine } \\
\text { hour }(\mathrm{hr})\end{array}$ & $\begin{array}{l}\text { Rain fall } \\
(\mathrm{mm})\end{array}$ & $\begin{array}{l}\text { ETo } \\
(\mathrm{mm} / \mathrm{day})\end{array}$ \\
\hline January & 25.5 & 8.5 & 65.9 & 2.04 & 6.8 & 43.19 & 3.53 \\
\hline February & 26.5 & 9.5 & 61.6 & 2.43 & 6.6 & 57.72 & 3.73 \\
\hline March & 26.4 & 10.8 & 64.3 & 2.40 & 6.1 & 124.89 & 3.80 \\
\hline April & 25.8 & 11.8 & 68.3 & 2.27 & 5.7 & 146.25 & 3.60 \\
\hline May & 25.0 & 12.1 & 74.4 & 2.20 & 5.5 & 215.09 & 3.20 \\
\hline June & 23.5 & 12.0 & 78.9 & 2.04 & 4.7 & 290.60 & 2.80 \\
\hline July & 22.0 & 11.9 & 82.8 & 1.92 & 3.1 & 259.51 & 2.50 \\
\hline August & 22.3 & 11.8 & 82.5 & 2.03 & 3.6 & 248.53 & 2.71 \\
\hline September & 23.0 & 11.7 & 80.2 & 2.03 & 4.4 & 247.97 & 3.03 \\
\hline October & 24.1 & 10.1 & 74.9 & 2.02 & 6.1 & 159.24 & 3.55 \\
\hline November & 24.5 & 8.5 & 70.4 & 2.23 & 7.2 & 69.18 & 3.53 \\
\hline December & 25.0 & 8.0 & 67.5 & 2.11 & 7.1 & 44.16 & 3.53 \\
\hline
\end{tabular}

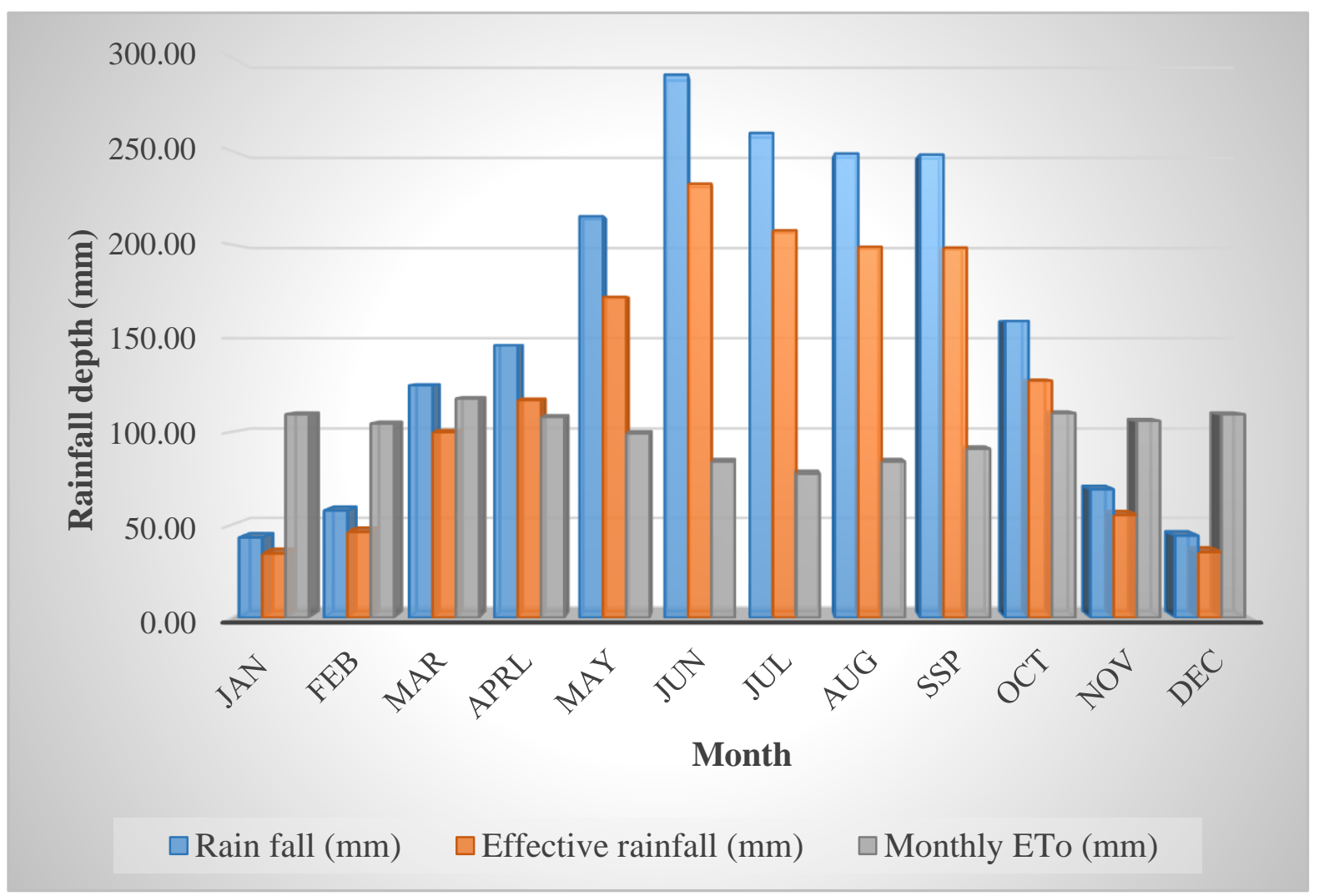

Figure2. Monthly rainfall and effective rainfall compared with evapotranspiration 
Table 2. Depth of water in $\mathrm{mm}$ applied at each growth stage for the treatments

Treatments

Growth Stage

\begin{tabular}{llllll} 
& \multicolumn{1}{c}{$\mathrm{D}$} & $\mathrm{M}$ & $\mathrm{L}$ & \multicolumn{2}{c}{ Total $(\mathrm{mm})$} \\
60\%ASMDL & 354.60 & 151.10 & 415.70 & 103.70 & 1025.10 \\
80\%ASMDL & 304.00 & 194.30 & 416.20 & 135.20 & 1049.70 \\
ASMDL* & 319.10 & 164.10 & 431.20 & 86.10 & 1000.50 \\
$120 \%$ ASMDL & 309.00 & 196.80 & 405.30 & 103.40 & 1014.50 \\
$140 \%$ ASMDL & 266.10 & 228.40 & 359.10 & 119.10 & 972.70 \\
\hline
\end{tabular}

Where

$$
\begin{array}{ll}
\text { I =initial stage }, & \mathrm{D}=\text { development stage, and } \\
\mathrm{M}=\text { mid- season stage }, & \mathrm{L}=\text { late stage }
\end{array}
$$

\section{RESULT AND DISCUSSION}

\subsection{Effect of soil moisture depletion levels on coffee growth parameter}

Plant height: As shown in Table 3 below, the over year's analysis of variance revealed that soil moisture depletion treatments had significant $(\mathrm{p}<0.05)$ effect on plant height. The tallest plant height was obtained from 120\% ASMDL (120\% allowable soil moisture depletion level) followed by $140 \%$ ASMDL. However, the shortest plant height was recorded from 80\% ASMDL. The plant height was linearly increased as soil moisture depletion level increased up to 120\% ASMDL, except fluctuation in some treatments. However, application of irrigation water beyond $120 \%$ ASMDL had significantly reduced the plant height.

In terms of stem girth, there were no significant differences $(\mathrm{p}<0.05)$ due to different soil moisture depletion levels (Table 3). The thicker stem girth was recorded from 120\% ASMDL and thinner from $60 \%$ ASMDL.

\subsection{Coffee Yield and water productivity}

Yield: the soil moisture depletion level significantly $(\mathrm{P}<0.05)$ affected coffee yield. The average highest coffee yield of $2330 \mathrm{Kg} / \mathrm{ha}$ was obtained from the $120 \%$ ASMDL by applying $10145 \mathrm{~m}^{3} / \mathrm{ha}$ of water, while the FAO recommended treatment of $100 \%$ ASMDL produced the lowest yield of 1780 $\mathrm{Kg} / \mathrm{ha}$. The $60 \%, 80 \%, 100 \%$ and $140 \%$ treatments were not statistically significant from each other. The yields of all treatments fluctuated between 100 and 120\% ASMDL soil moisture depletion levels (Table 3).

The coffee yield linearly increased as soil moisture depletion level increased until 120\% ASMDL, beyond this depletion level yield started to decline. When compared with the FAO recommendation to $120 \%$ ASMDL, a $30 \%$ yield increment was obtained, but quickly declined to $11.9 \%$ at $140 \%$ ASMDL during 2008 and 2010 years. The sharp reduction of $19.3 \%$ yield was observed at $60 \%$ ASMDL as compared to $120 \%$ ASMDL treatment. This occurs due to frequent application of water that leaches out important plant nutrients, and consequently stressed the plants nutrient. The reduction of coffee 
yield beyond 120\% ASMDL treatment is due to the introduction of soil moisture stress, and consequently this leads to plants water stress.

Different authors reported that reducing and increasing the amount of water application interval significantly affected yield of different crops. This result is in agreement with the finding of Yaziz and Tefera's (2016), study conducted on Maize at Tepi, South West of Ethiopia. Ashebir and Demeke (2016), obtained the lowest yield of maize at 100\% ASMDL at Pawe, Ethiopia. They reported yield of maize increased as soil moisture depletion increased or decreased. Robel et al (2019) on maize reported that the maximum or minimum soil moisture depletion level reduced crop yield, which agrees with current finding. Hassan and Sarkar (1999) concluded that application of further irrigation in chickpea gradually decreased yield and water use efficiency, causing the wastage of irrigation water.

Table3. Statistical analysis of yield and growth parameter of the treatment

\begin{tabular}{|l|l|l|l|l|}
\hline Treatments & $\begin{array}{l}\text { Plant Height* } \\
(\mathrm{cm})\end{array}$ & $\begin{array}{l}\text { Stem girth } \\
@ 5 \mathrm{~cm}(\mathrm{~cm})\end{array}$ & $\begin{array}{l}\text { Yield } \\
(\mathrm{Kg} / \mathrm{ha})^{*}\end{array}$ & $\begin{array}{l}\text { Water Productivity* } \\
\left(\mathrm{Kg} / \mathrm{m}^{3}\right)\end{array}$ \\
\hline $60 \%$ ASMDL & $125.93^{\mathrm{bc}}$ & 20.08 & $1881^{\mathrm{b}}$ & $1.83^{\mathrm{b}}$ \\
\hline $80 \%$ ASMDL & $122.67^{\mathrm{c}}$ & 23.24 & $1950^{\mathrm{b}}$ & $1.86^{\mathrm{b}}$ \\
\hline ASMDL & $152.2^{\mathrm{a}}$ & 22.16 & $1781^{\mathrm{b}}$ & $1.82^{\mathrm{b}}$ \\
\hline $120 \%$ ASMDL & $163.87^{\mathrm{a}}$ & 23.22 & $2332^{\mathrm{a}}$ & $2.30^{\mathrm{a}}$ \\
\hline $140 \%$ ASMDL & $154.22^{\mathrm{ab}}$ & 22.94 & $1993^{\mathrm{b}}$ & $2.05^{\mathrm{ab}}$ \\
\hline LSD at 0.05 & 29.27 & $\mathrm{~ns}$ & 2.67 & 0.025 \\
\hline CV $\%$ & 10.81 & 11.68 & 7.13 & 6.83 \\
\hline
\end{tabular}

Means with the same letter are not statically significant

Water productivity: The results of mean from the data showed that the use of different soil moisture depletion levels significantly affects $(\mathrm{P}<0.05)$ water productivity in coffee production. The highest water productivity of $2.30 \mathrm{Kg} / \mathrm{m}^{3}$ was obtained at $120 \%$ ASMDL followed by $140 \%$ ASMDL $(2.05$ $\mathrm{Kg} / \mathrm{m}^{3}$ ) (Table 3). Whereas, the minimum was obtained from FAO recommended ASMDL (1.78 $\mathrm{Kg} / \mathrm{m}^{3}$ ) followed by $60 \%$ ASMDL $\left(1.83 \mathrm{Kg} / \mathrm{m}^{3}\right)$ (Table 3$)$. From the present study, the highest water productivity was obtained from the treatment which has the maximum yield. Therefore, crop water productivity was linearly increased as soil moisture depletion level rise from 60\% ASMDL to $120 \%$ ASMDL, however, water productivity was gradually decreased at $140 \%$ ASMDL as interval of irrigation increased that leads to crop stress which is similar with the findings of Muktar and Yigezu (2016).

\section{CONCLUSION AND RECOMMENDATION}

The knowledge of proper irrigation water management is an important practical consideration to improve water use efficiency in irrigated agriculture which is governed by soil moisture depletion. Water use efficiency can be improved by proper irrigation scheduling, which is determined by crop evapotranspiration (ETc). Optimization of soil moisture depletion level is a major limiting factor in agricultural production systems. Effective use of available water with appropriate irrigation scheduling has a significant implication on irrigated agriculture. The scheduling of irrigation for coffee is based on FAO recommendation and requires adjustment to local condition.

From the result obtained, there is a significant difference among treatments. It was observed that decreasing or increasing the amount of allowable soil moisture depletion level had significantly reduced the coffee yield, water productivity and plant height. The, total irrigation water requirement of coffee Arabica in the agro ecology of Gera is $10145 \mathrm{~m}^{3} / \mathrm{ha}$ and it requires $3090 \mathrm{~m}^{3} / \mathrm{ha}$ for the initial, $1968 \mathrm{~m}^{3} / \mathrm{h}$ a for the mid-season, $4053 \mathrm{~m}^{3} / \mathrm{ha}$ for the development and $1034 \mathrm{~m}^{3} / \mathrm{ha}$ during the late season, i,e, during buildup and initiation of flower buds, flower bud formation and flowering, fruit development and maturity and up to harvesting the coffee bean, respectively. 
It is recommended to give the irrigation water at an interval of 30 days for the initial, development and mid-season and after 32 days of interval during the late season using the water can irrigation on sandy clay loam soil in the agro ecology of Gera and its surrounding.

Even though this study provided the optimal depletion level starting from the stage where the crop can give yield at the field, further, research is required to determine the exact soil moisture depletion level in a control environment starting from the nursery stage and other research is also required to investigate the coffee berry disease (CBD) resistance of coffee using irrigation.

\section{ACKNOWLEDGMENT}

The Authors are thankful to staff of Jimma Agricultural Research Center and Gera Agricultural Research Sub-Center in general for providing necessary support to conduct the study. Our special thanks also goes to Ethiopian Institute of Agricultural Research (EIAR) for financial support to conduct the study in particular, researcher as well as technicians in the natural resource directorate.

\section{REFERENCES}

[1] Allen, R., L.S. Pereira, D. Raes, and M. Smith (1998). Crop evapotranspiration Guidelines for computing crop water requirements. FAO Irrigation and Drainage Paper No 56. Rome, Italy.

[2] Ashebir, H., Demeke T. 2017. Determination of Optimum Irrigation Scheduling and Water Use Efficiency for Maize Production in North-West Ethiopia. Journal of Natural Sciences Research, 2224-3186.

[3] Gomez, K.A. and Gomez, A.A., 1984. Statistical procedures for agricultural research. John Wiley and Sons.

[4] Hassan AA, Sarkar AA (1999) Water use and yield relations of chickpea as influenced by different irrigation levels. Thai J Agric Sci 32: 549-354.

[5] Michael AM (1999). Irrigation: Theory and Practice. Vikas Publishing House, New Delhi, India. pp 530539.

[6] Muktar BY, Yigezu TT (2016). Determination of Optimal Irrigation Scheduling for Maize (Zea mays L.) at Teppi, Southwest of Ethiopia. Irrigation Drainage Systems Engineering 5(3): 173.

[7] Robel A, Addisu A, Minda T. Determination of Optimal Irrigation Scheduling for Soybean (Glycine max L.) Yield and Water Productivity at Jimma, South West Ethiopia. Agri Res\& Tech: Open Access J. 2019; 19(4)

[8] Savva, A.P. and K. Frenken (2002). Crop water requirements and irrigation scheduling. FAO Sub-Regional Office for East and SouthernAfrica, Harare. Zimbabwe. 132p.

[9] Silva, C. A., R.E. F. Teodoro, B. Melo, 2008. Productivity and yield of coffee plants submitted to irrigation slides. Brazilian Agricultural Research 43: 387-394.

[10] Tadesse Bedane, Minda., 2019. Spatial and temporal variability of coffee (Coffeaarebica L.) Water and irrigation requirement mapping for Jimma zone, Hawassa University.

[11] Yaziz, B. and Tefera, T. 2016. Determination of Optimal Irrigation Scheduling for Maize (Zea Mays) at Teppi, Southwest of Ethiopia. Irrigation \& Drainage Systems Engineering, 5(3).

Citation: Etafa Tilahun, e.al., " Determination of Optimal Irrigation Scheduling for Coffee (Coffee Arabica L.) at Gera, South West of Ethiopia." International Journal of Research Studies in Agricultural Sciences (IJRSAS), 2021; 7(1), pp. 37-42, https://doi.org/10.20431/2454-6224.0701005

Copyright: () 2021 Authors. This is an open-access article distributed under the terms of the Creative Commons Attribution License, which permits unrestricted use, distribution, and reproduction in any medium, provided the original author and source are credited. 